\title{
Thymol and Carvacrol Downregulate the Expression of Salmonella typhimurium Virulence Genes during an In Vitro Infection on Caco-2 Cells
}

\author{
Giulia Giovagnoni ${ }^{1}$, Barbara Rossi ${ }^{2}$, Benedetta Tugnoli ${ }^{2}$, Federico Ghiselli $^{1}{ }^{\circledR}$, Andrea Bonetti ${ }^{1}$, \\ Andrea Piva ${ }^{1,2}$ and Ester Grilli $1,3, *$ \\ 1 DIMEVET, Dipartimento di Scienze Mediche Veterinarie, Università di Bologna, Via Tolara di Sopra 50, \\ 40064 Ozzano dell’Emilia (BO), Italy; giulia.giovagnoni4@unibo.it (G.G.); federico.ghiselli4@unibo.it (F.G.); \\ andrea.bonetti15@unibo.it (A.B.); andrea.piva@unibo.it (A.P.) \\ 2 Vetagro S.p.A., via Porro 2, 42124 Reggio Emilia, Italy; barbara.rossi@vetagro.com (B.R.); \\ benedetta.tugnoli@vetagro.com (B.T.) \\ 3 Vetagro Inc., 116 W. Jackson Blvd., Suite \#320, Chicago, IL 60604, USA \\ * Correspondence: ester.grilli@unibo.it
}

Received: 20 May 2020; Accepted: 6 June 2020; Published: 7 June 2020

check for updates

\begin{abstract}
Salmonella typhimurium is one of the major bacteria responsible for gastroenteritis in humans caused by foodborne pathogens. As pork is one of the main routes of transmission, bioactive compounds used as feed additives may be an important strategy to control Salmonella typhimurium. The aim of this study was to assess the antimicrobial activity of several organic acids and nature identical compounds against Salmonella typhimurium ATCC ${ }^{\circledR}$ 6994 ${ }^{\mathrm{TM}}$. Moreover, the effect of sub-lethal concentrations of thymol and carvacrol in counteracting a Salmonella typhimurium in vitro infection on Caco-2 cells was evaluated, focusing on the maintenance of the epithelial barrier and the alteration of Salmonella virulence genes. The results showed a protective effect of the compounds on the integrity of the intestinal monolayer, improving transepithelial electrical resistance and bacterial translocation compared to the non-treated cells. A real-time PCR study highlighted a significant downregulation of the main virulence genes of Salmonella (hil A, $\operatorname{prg} H, \operatorname{inv} A, \operatorname{sip} A, \operatorname{sip} C, \operatorname{sip} D, \operatorname{sop} B$, sopE2). These findings indicate that thymol and carvacrol could be good candidates for the control of Salmonella typhimurium in pigs.
\end{abstract}

Keywords: Salmonella typhimurium; tight junctions; epithelial barrier; virulence genes; nature identical compounds; thymol; carvacrol; antimicrobial activity; feed additives

\section{Introduction}

Salmonella typhimurium is a Gram-negative foodborne pathogen, reported as the second and third most common cause of human gastrointestinal infections in Europe and the United States, respectively [1,2]. Among European cases, 27.3\% of the isolated strains were associated with matrices of porcine origin, confirming this species as one of the main pathways of transmission to humans $[1,3]$. S. typhimurium infection in pigs must not be underestimated, since it can cause enterocolitis, but it can also persist asymptomatically, making the pig an important reservoir of the pathogen, reducing productivity and average daily gain [4,5]. In the latter case, S. typhimurium colonizes the gastrointestinal tract of the pig in a persistent and chronic way and, during periods of stress, this asymptomatic colonization often flares up [6]. The most dangerous situations are during transport and at the slaughterhouse, where the spread of this pathogen is amplified and the contamination of food through fecal matter becomes the main route of transmission to humans $[7,8]$. 
The pathogenesis of Salmonella spp. is widely studied and it is known to be associated with Salmonella pathogenicity islands (SPI) [9]. SPI-1 and SPI-2, in particular, encode for two type III secretion systems (T3SS), a complex apparatus composed of structural, translocator and effector proteins that allow the entry and the maintenance of bacteria in the host intestinal cell [10]. Structural proteins are responsible for the assembly of the T3SS apparatus, formed by two rings crossing the inner and outer bacterial membrane, linked to a needle-like system that pierces the host cellular membrane $[10,11]$. The latter structure is crucial for the transport of the effector proteins, delivered by translocators from the bacterial cell into the host: here, effectors manage fundamental changes enabling key steps for Salmonella pathogenesis [12]. During the bacterial infection, Salmonella invade the enterocyte and survive into the host cytoplasm surrounded by large vesicles, called Salmonella-containing vacuoles (SCV) [13]. The disruption of the intestinal epithelial barrier, as a consequence of the disruption of tight junctions (TJ), is the main issue of the infection, giving rise to diarrhea-generating gastroenteritis. The Caco-2 cell monolayer system is a proven in vitro model for studying the structure and functionality of TJ, even during bacterial challenges [14,15]. In fact, most enteric pathogens are known to perturb the intestinal epithelial barrier, impacting transepithelial electrical resistance (TER) or paracellular permeability, and altering the arrangement of TJ with different mechanisms. It has been demonstrated that several effector proteins encoded by SPI-1, such as SipA, SopB, SopE, and SopE2, are responsible for alteration of these parameters [16].

Nowadays, it is crucial to use alternatives to antibiotics in the control of S. typhimurium. Nature identical compounds (NIC) have been widely studied for their antibacterial properties [8,17], which makes them suitable candidates as feed additives.

The aim of the study was to investigate the role of sub-lethal concentrations of thymol and carvacrol in counteracting a S. typhimurium infection of Caco-2 cells, focusing on the maintenance of the epithelial barrier and the alteration of Salmonella virulence genes.

\section{Materials and Methods}

\subsection{Bacterial Strain and Culture Conditions}

The strain used in this study was the ATCC ${ }^{\circledR}$ Salmonella typhimurium $6994^{\mathrm{TM}}$. S. typhimurium was conserved at $-80^{\circ} \mathrm{C}$ in Brain Heart Infusion broth (BHI) supplemented with $20 \%(v / v)$ glycerol, and it was recovered in BHI at $37^{\circ} \mathrm{C}$. The identification was carried out using Microbact ${ }^{\mathrm{TM}}$ 24E (Oxoid, Basingstoke, United Kingdom).

\subsection{Chemicals and Test Solutions}

Citric acid, sorbic acid, benzoic acid, butyric acid, hexanoic acid, thymol, vanillin, carvacrol, and eugenol were purchased from Alfa Aesar (Thermo Fisher GmbH, Kandel, Germany). Stock solutions of organic acids and NIC were prepared in BHI and BHI supplemented with $70 \%(v / v)$ ethanol, respectively. All solutions were buffered to $\mathrm{pH} 6.5$ and filter-sterilized, then they were conserved at $+4{ }^{\circ} \mathrm{C}$ and brought back to room temperature before each use.

\subsection{Minimal Inhibitory Concentration of Bioactive Compounds}

The minimal inhibitory concentrations (MIC) of organic acids and NIC were determined in triplicate using the broth microdilution method in 96-well microtiter plates. Citric acid, sorbic acid, benzoic acid, butyric acid, and hexanoic acid were tested at final concentrations ranging from 100 to $1.56 \mathrm{mM}$ (2-fold dilutions), whereas thymol, vanillin, carvacrol, and eugenol from 7.5 to $0.12 \mathrm{mM}$ (2-fold dilutions). An overnight bacterial culture of $S$. typhimurium was diluted to obtain an inoculum of $10^{6} \mathrm{CFU} / \mathrm{mL}$. For each bioactive compound, the MIC value was defined as the lowest concentration that resulted in null absorbance $(630 \mathrm{~nm})$ registered with Varioskan ${ }^{\mathrm{TM}}$ LUX Multimode Microplate Reader (Thermo fisher Scientific Inc., Waltham, MA, USA) after $24 \mathrm{~h}$ of incubation at $37^{\circ} \mathrm{C}$. 


\subsection{Time-Kill Curve of Thymol and Carvacrol}

A time-kill assay was performed in order to evaluate the bactericidal effect of thymol and carvacrol against $S$. typhimurium over time. S. typhimurium, diluted at $10^{6} \mathrm{CFU} / \mathrm{mL}$ in $\mathrm{BHI} \mathrm{pH} 6.5$ from an overnight culture, was incubated at $37^{\circ} \mathrm{C}$ for $24 \mathrm{~h}$ without any substance (CTR), and either with thymol or carvacrol at 1.87 (MIC), 0.94 , and $0.47 \mathrm{mM}$. Bacteria were counted at the inoculation time (0 h), every hour for the following $8 \mathrm{~h}$, and then after $24 \mathrm{~h}$ of incubation. At each time-point, a $100 \mu \mathrm{l}$ aliquot was collected from each tube and the samples were serially (10-fold) diluted in saline solution. Dilutions were then plated on BHI agar plates and incubated at $37^{\circ} \mathrm{C}$ for $24 \mathrm{~h}$.

\subsection{Effect of Thymol and Carvacrol on Intestinal Caco-2 Cells Monolayer Integrity}

The human colon adenocarcinoma cell line (Caco-2) was obtained from DSMZ (DSMZ-German Collection of Microorganisms and Cell Cultures, Leibniz Institute, Braunschweig, Germany). Caco-2 cells were seeded at a density of $1.5 \times 10^{5}$ cells/well onto 12 well transwell polyethylene terephthalate inserts (3.0 $\mu \mathrm{m}$ pore; Corning Incorporated, Corning, NY, USA) and were maintained at $37^{\circ} \mathrm{C}$, in an atmosphere containing $5 \% \mathrm{CO}_{2}$ at $95 \%$ relative humidity, in DMEM supplemented with $10 \%$ fetal bovine serum (FBS), 1\% non-essential amino acids (NEAA), 1\% penicillin/streptomycin (P/S) and 1\% L-Glutamine. The medium was replaced every other day, both before and after cells reached confluence. Moreover, confluent cells were monitored measuring transepithelial electrical resistance (TER) at the same time as the change of medium, using an epithelial tissue voltohmmeter (Millicell ERS-2, Merck KGaA, Darmstadt, Germany).

Cells were used for bacterial challenge 28 days after the seeding on filters, once TER values were stable. On day 28, TER was measured right before the start of the challenge and the cellular medium was removed and substituted with the same medium without P/S. Cells were apically challenged with S. typhimurium in exponential phase at a concentration of $10^{5} \mathrm{CFU} / \mathrm{mL}$ with $\mathrm{EtOH}$ in a concentration equivalent to that found in the treated groups (challenged control, CTR + ), and with either thymol or carvacrol at $0.47 \mathrm{mM}(n=5)$. A group in the same conditions of CTR+, but without bacterial challenge, was identified as the non-challenged control (CTR-). In order to determine the intestinal monolayer integrity and the infection process, TER and bacterial translocation were examined during a $4 \mathrm{~h}$ challenge at 2 and $4 \mathrm{~h}$. For bacterial translocation, a $100 \mu \mathrm{L}$ aliquot of the basolateral medium was collected, serially (10-fold) diluted in saline solution and seeded on BHI agar plates in order to count how many bacteria translocated from the apical to the basolateral side of the intestinal monolayer.

\subsection{Determination of Salmonella Virulence mRNA Expression}

mRNA expression analyses were performed by extracting RNA from S. typhimurium cultures with thymol and carvacrol. In brief, $10^{6} \mathrm{CFU} / \mathrm{mL}$ of $S$. typhimurium was incubated for $4 \mathrm{~h}$ at $37^{\circ} \mathrm{C}$ with thymol or carvacrol at $0.47 \mathrm{mM}$. A control group with and without ethanol was also performed (EtOH; CTR). After incubation, the bacterial cultures were centrifuged for $5 \mathrm{~min}$ at $5000 \times \mathrm{g}$ and the supernatants were discarded. The pellets were resuspended in $100 \mu \mathrm{L}$ of TE buffer supplemented with $1 \mathrm{mg} / \mathrm{mL}$ of lysozyme and incubated for $10 \mathrm{~min}$ at $37^{\circ} \mathrm{C}$. NucleoSpin ${ }^{\circledR}$ RNA Kit (Macherey-Nagel $\mathrm{GmbH} \&$ Co. KG, Düren, Germany) was used for RNA extraction and purification in accordance with manufacturer's instructions. RNA yield and quality were verified spectrophotometrically using A230, A260, and A280 nm measurements ( $\mu$ Drop $^{\mathrm{TM}}$ Plate and Varioskan ${ }^{\mathrm{TM}}$ LUX, Thermo fisher Scientific Inc., Waltham, MA, USA). The extracted RNA was converted into cDNA using iScript ${ }^{\mathrm{TM}} \mathrm{cDNA}$ Synthesis Kit (Bio-Rad Laboratories, Inc., Hercules, CA, USA) according to manufacturer's instructions.

After cDNA synthesis, $S$. typhimurium virulence gene expression was determined with a real-time PCR, testing the genes listed in Table 1, using CFX96 ${ }^{\mathrm{TM}}$ Real-Time PCR Detection System (Bio-Rad Laboratories, Inc., Hercules, CA, USA). The reaction contained $5 \mu \mathrm{L}$ of $2 \times$ iTaq $^{\text {TM }}$ Universal SYBR $^{\circledR}{ }^{\circledR}$ Green Supermix (Bio-Rad Laboratories, Inc., Hercules, CA, USA), 200 or $600 \mathrm{nM}$ of each primer, $2 \mu \mathrm{L}$ of $5 \mathrm{ng} / \mu \mathrm{L}$ cDNA, and nuclease-free water up to the final volume of $10 \mu \mathrm{L}$. The samples were analyzed 
under the following conditions: $3 \mathrm{~min}$ at $95^{\circ} \mathrm{C}$, followed by 40 cycles of $95^{\circ} \mathrm{C}$ for $10 \mathrm{~s}$ and $60{ }^{\circ} \mathrm{C}$ for $30 \mathrm{~s}$. Specificity of each reaction was evaluated by melting-curve analysis with $0.5^{\circ} \mathrm{C} / \mathrm{s}$ heating rate from 55 up to $95^{\circ} \mathrm{C}$.

mRNA expression was normalized using $r p o D$ as housekeeping gene. After determining the threshold cycle $(\mathrm{Ct})$ for each gene, the relative changes in mRNA expression of $S$. typhimurium grown with thymol and carvacrol compared to controls were calculated using the $2^{-\Delta \Delta C t}$ method [18].

Table 1. List of primers used for real-time PCR.

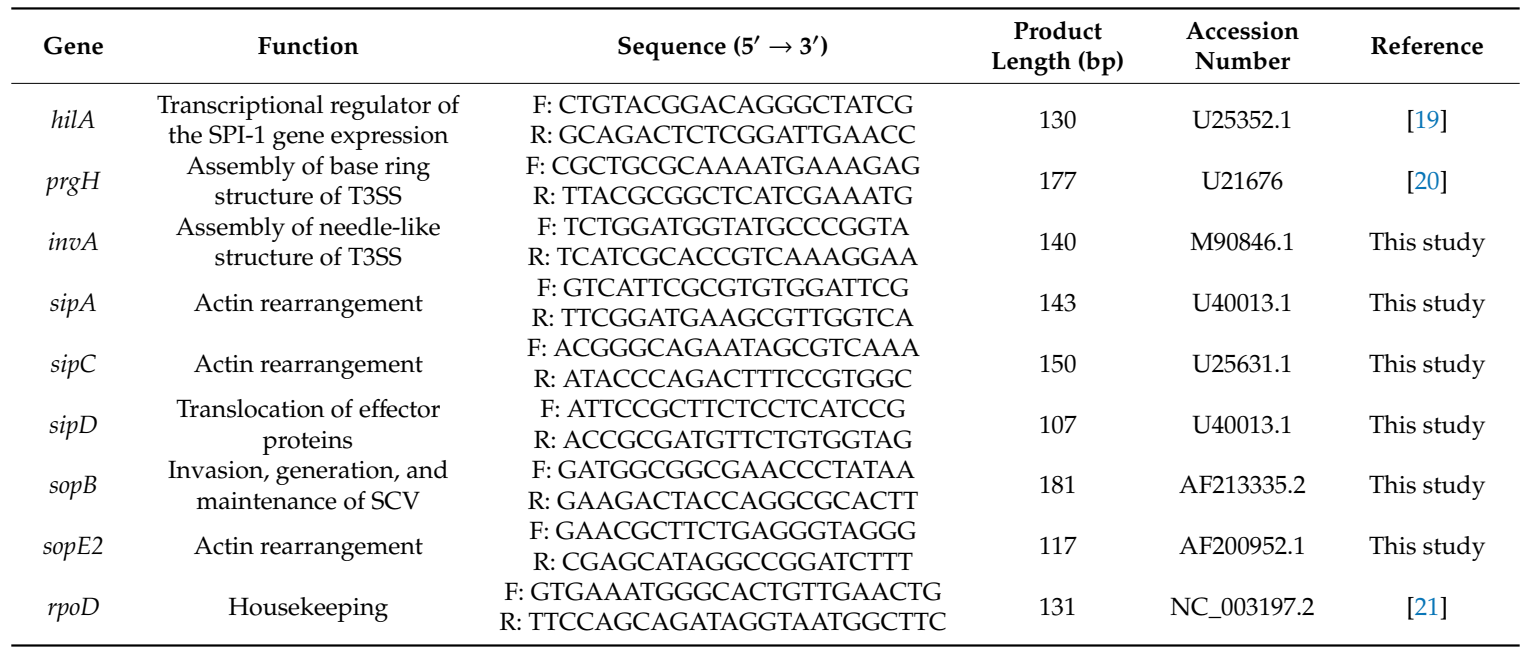

\subsection{Statistical Analysis}

The data were analyzed with GraphPad Prism v. 8.4.1 (GraphPad Software, Inc., San Diego, CA, USA) and differences were considered significant at $p \leq 0.05$. For cell culture and mRNA expression data, two-way ANOVA was performed, followed by the Tukey post hoc test for multiple comparisons.

\section{Results}

\subsection{Thymol and Carvacrol Have the Lowest MIC among Tested Bioactive Compounds}

The antimicrobial activity of organic acids and NIC against S. typhimurium are reported in Figure $1 \mathrm{~A}, \mathrm{~B}$, respectively. Citric and butyric acid did not inhibit $S$. typhimurium, while the MIC value of sorbic, benzoic, and hexanoic acid was defined as $100 \mathrm{mM}$. All the tested NIC were effective at lower concentrations than organic acids. In particular, vanillin inhibited S. typhimurium at $7.5 \mathrm{mM}$, eugenol at $3.75 \mathrm{mM}$, and both thymol and carvacrol at $1.87 \mathrm{mM}$.

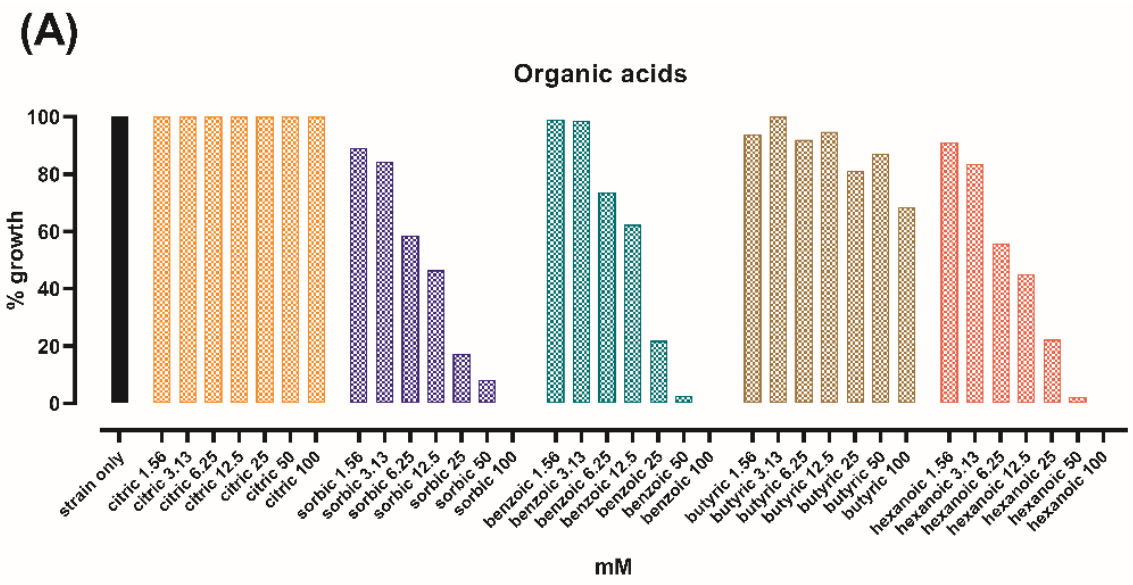

Figure 1. Cont. 
(B)

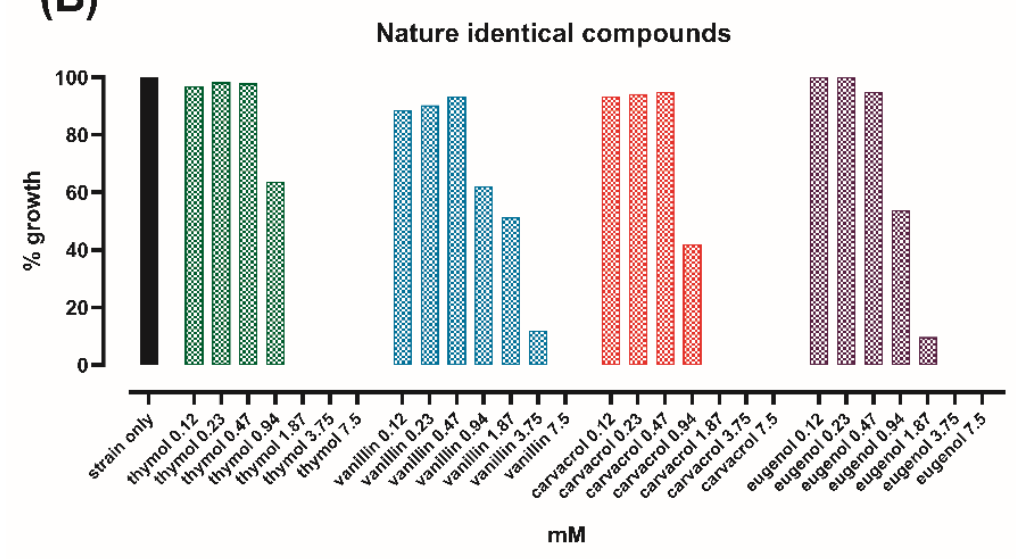

Figure 1. Salmonella typhimurium growth after $24 \mathrm{~h}$ in the presence of organic acids (A) or nature identical compounds (B). Bacterial growth is expressed as a percentage relative to the control (strain only).

\subsection{The Bactericidal Effect of Thymol and Carvacrol Is Dose-Dependent}

The time-kill study highlighted a dose-dependent effect over time for both thymol and carvacrol, as shown in Figure 2. The highest concentrations tested $(1.87 \mathrm{mM})$, corresponding to the MIC value defined by the microdilution method, had a strong bactericidal effect against $S$. typhimurium immediately after inoculation. Thymol and carvacrol at $0.94 \mathrm{mM}$ gradually reduced Salmonella viability during the first $8 \mathrm{~h}$, to reach a complete kill within $24 \mathrm{~h}$. Finally, the two NIC at $0.47 \mathrm{mM}$ did not have any direct antibacterial activity, since the growth of $S$. typhimurium was comparable to the control without substances.

\section{Time-kill curve}

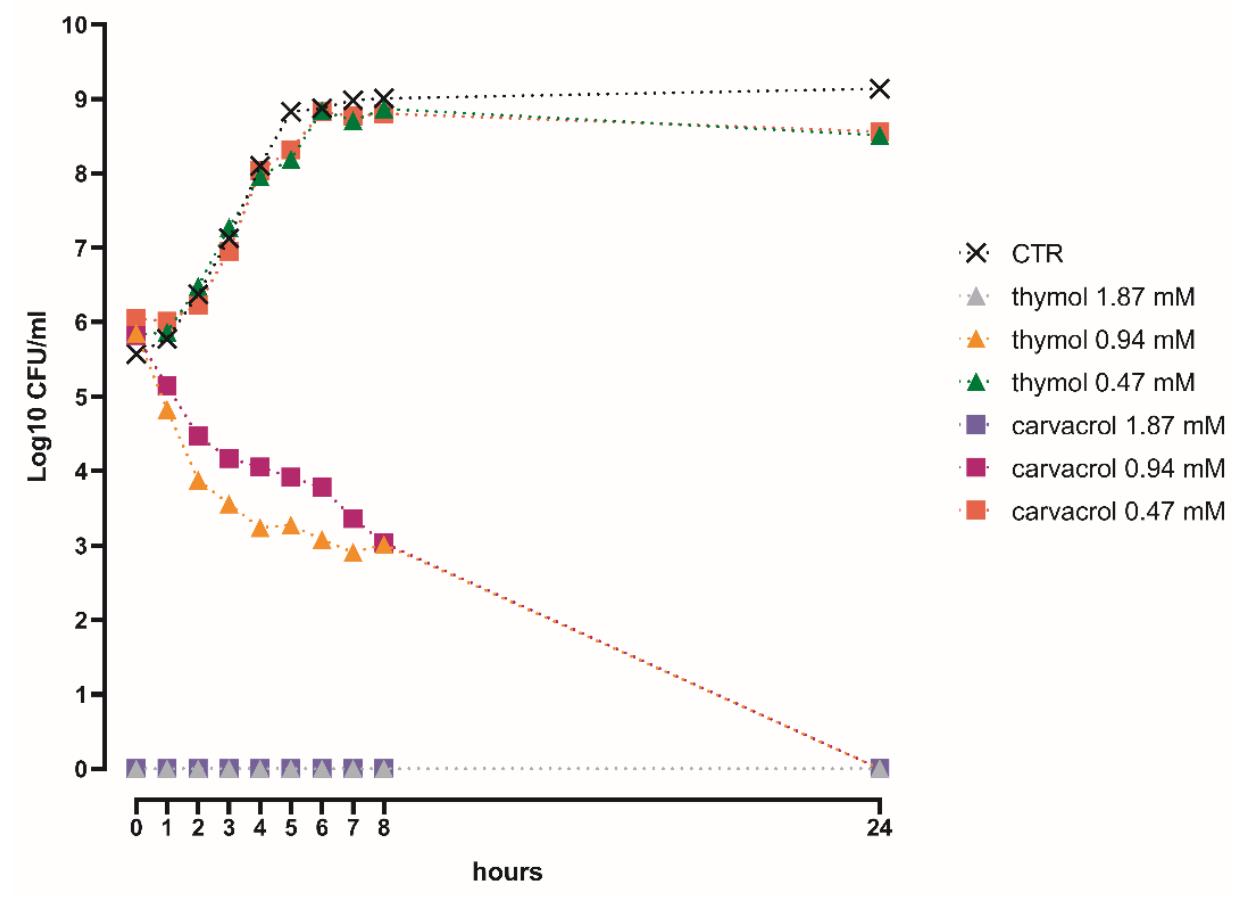

Figure 2. Time-kill curve of thymol or carvacrol 1.87, 0.94, and $0.47 \mathrm{mM}$ against S. typhimurium. 
3.3. Thymol and Carvacrol at Sub-Lethal Concentrations Can Counteract a S. typhimurium Challenge on Caco-2 Cells

Results of transepithelial electrical resistance (TER) and bacterial translocation are represented in Figure 3A,B, respectively. The challenge with S. typhimurium on Caco-2 cells induced a drop in TER and an increase in bacterial translocation. After $2 \mathrm{~h}$ no differences were shown in the measurement of TER between the two control groups, while thymol and carvacrol increased TER by more than $30 \%$ $(p<0.0001)$. At $4 \mathrm{~h}$ post-challenge, CTR + showed a $25 \%$ drop in TER. Cells treated with thymol or carvacrol maintained a higher TER compared to both CTR+ and CTR $-(p<0.0001)$.

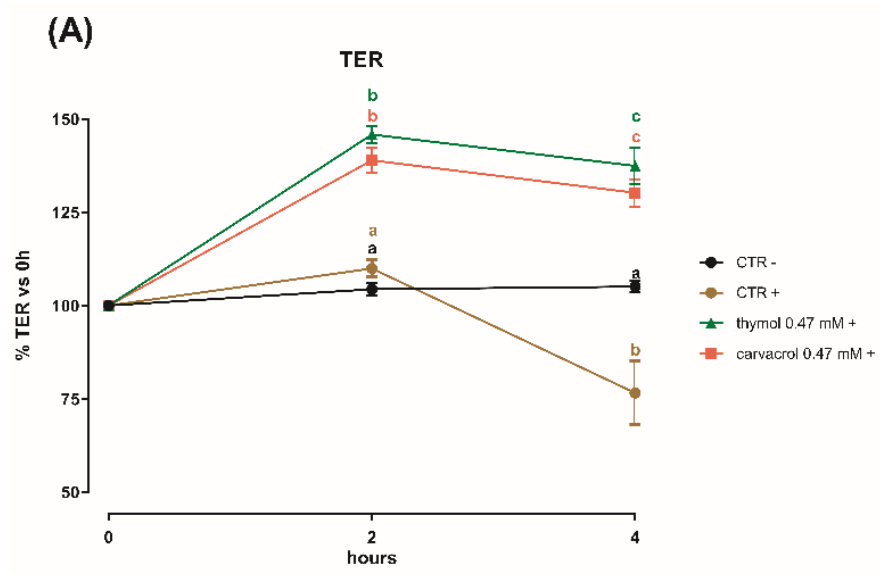

(B)

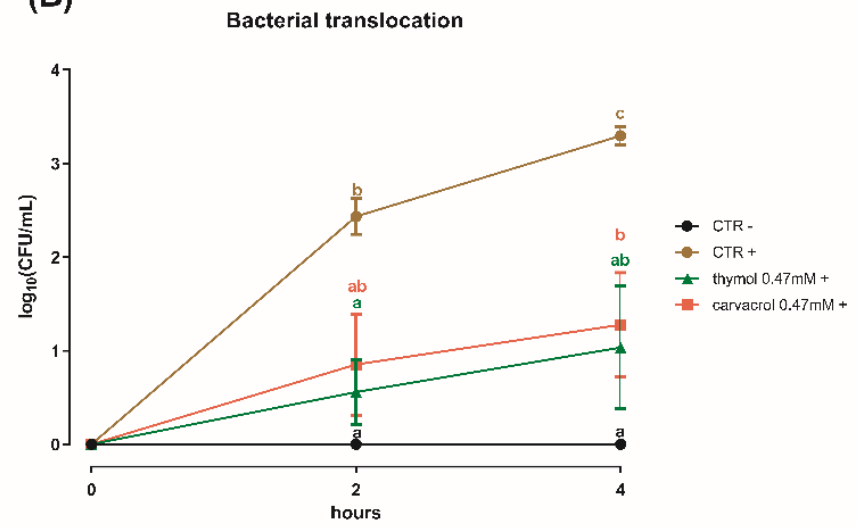

Figure 3. (A) Transepithelial electrical resistance (TER) and (B) bacterial translocation of Caco-2 cells cultured with ethanol (CTR-; CTR+), thymol, or carvacrol $0.47 \mathrm{mM}$ post-challenge with S. typhimurium $(+)$, or without bacterial challenge $(-)$. Data are presented as mean \pm SEM. Different letters indicate statistical significance with $p<0.05$.

Differences were also observed for bacterial translocation. After $2 \mathrm{~h}, \mathrm{CTR}+$ results were significantly different compared to CTR- and the thymol treated groups $(p<0.05)$. At $4 \mathrm{~h}$, bacteria counted in the basolateral side of both NIC treated cells were significantly lower than in the CTR+ $(p<0.05)$; however, thymol at $0.47 \mathrm{mM}$ was comparable to the non-challenged control at both time-points.

\subsection{Sub-Lethal Concentrations of Thymol and Carvacrol Downregulate Virulence Genes of S. typhimurium}

All of the S. typhimurium virulence genes that were investigated were downregulated by thymol and carvacrol (Figure 4). No differences were found between the two control groups (CTR and EtOH) and for this reason EtOH data are not shown. Thymol and carvacrol decreased the expression of all the 
genes, compared to CTR $(p<0.05)$. Moreover, mRNA expression was significantly lower in treatment with carvacrol than thymol, except for sipC.

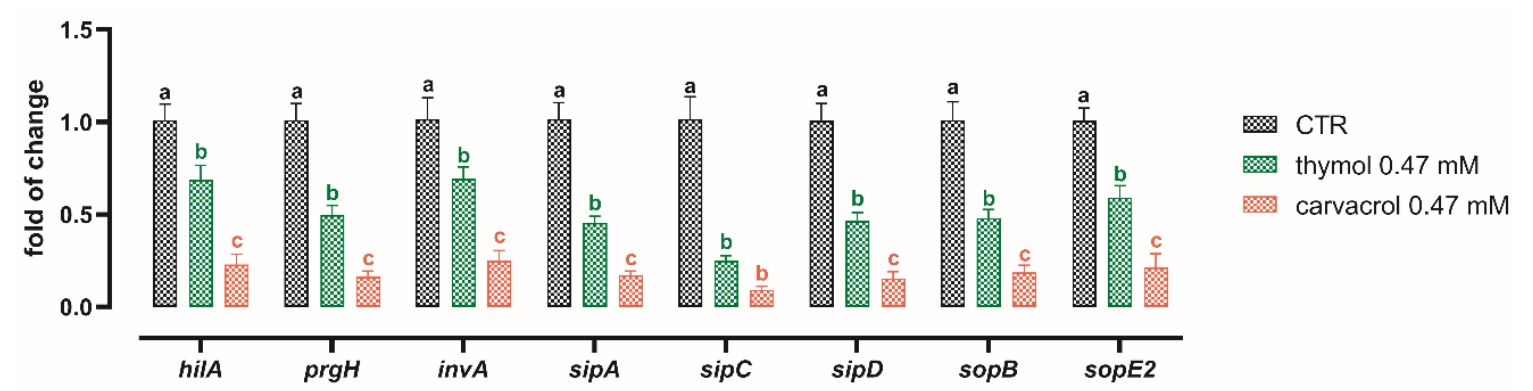

Figure 4. mRNA expression of hilA, $\operatorname{prg} H, \operatorname{inv} A, \operatorname{sip} A, \operatorname{sip} C, \operatorname{sip} D, \operatorname{sop} B, \operatorname{sop} E 2$ from S. typhimurium cultures alone (CTR), and with either thymol or carvacrol $0.47 \mathrm{mM}$. Data are presented as mean \pm SEM. Different letters indicate statistical significance with $p<0.05$.

\section{Discussion}

S. typhimurium is one of the major foodborne pathogens worldwide. Since pigs are usually asymptomatic, the main concern related to swine salmonellosis is the sly transmission to humans through pork products. In order to prevent contamination of animal products at the slaughterhouse, the key is to prevent the colonization of pigs during the production cycle. In the past years, several strategies have been studied for the reduction of Salmonella prevalence in swine farms, including measures of hygiene and biosecurity, vaccine programs, and feeding practices [22]. Focusing on feeding, the main principle is the balancing of intestinal microflora in favor of beneficial bacteria, avoiding the harmful colonization of Salmonella. For this purpose, in the last decades several feed additives were adopted, as organic acids and botanicals, thanks mainly to their antimicrobial properties [23,24]. In fact, the role of organic acids in killing harmful bacteria, as well as in the alteration of Salmonella gene expression, has been investigated for many years [25]. Although herbal extracts are a relatively new approach compared to acids, the antimicrobial action of these compounds is equally powerful [26].

The approach of this study was to perform a preliminary screening of organic acids and NIC with the aim to detect the molecules with the greatest direct antimicrobial activity against S. typhimurium. This first screening revealed that NIC had stronger antimicrobial activity than organic acids, which is consistent with other reports [27-29], and this would offer an explanation in the theory of acid tolerance of S. typhimurium in response to low $\mathrm{pH}$ [30]. Then, as thymol and carvacrol were identified as the most effective molecules, they were used in a time-kill assay, with the purpose of assessing sub-inhibitory concentrations to test on cell cultures. The protective effects of thymol and carvacrol on the in vitro intestinal monolayer were verified by measuring functionality and integrity parameters (TER, bacterial translocation) of Caco-2 cells infected with S. typhimurium.

Caco-2 cells, together with other human adenocarcinoma cell lines, mimic the intestinal epithelium by polarizing on permeable filters [31]. This system is suitable for bacterial challenges that interfere with the intestinal monolayer, and it is a standardized approach for studying S. typhimurium invasivity [15]. In the model of Finlay and Falkow [15], S. typhimurium $\left(10^{7}\right)$ was added on 10-14 day-old Caco-2 cells on 3 um filters. Authors were able to observe bacteria invading host cytoplasm enclosed in SCV by scanning and transmission electron microscopy. Moreover, consistent with our results, bacteria appeared in the basolateral medium $2 \mathrm{~h}$ post-challenge, while transepithelial electrical resistance (TER) dropped after 3-4 h, suggesting that our challenge worked correctly. In this study, thymol and carvacrol were able to counteract the bacterial challenge by increasing TER values even beyond the non-challenged control and maintaining the high values throughout the experiment. Transepithelial electrical resistance is an indicator of the health status and the tightness of the intestinal epithelium [32], and it is reported that many NIC have anti-inflammatory and antioxidant activity, that in turn can improve gut morphology and integrity as mediated by tight junction proteins [33]. In parallel, thymol 
and carvacrol also reduced bacterial translocation across the monolayer. Several studies investigated the role of carvacrol against the invasion of IPEC-J2 cells by S. typhimurium [34,35]. Inamuco et al. [34] found that carvacrol $0.5 \mathrm{mM}$ significantly reduced the invasion of porcine epithelial cells, probably due to the loss of functionality of flagella. A subsequent study by Burt et al. [35] confirmed the results obtained by Inamuco et al., assuming that virulence factors could be affected by carvacrol. In a study conducted by Zhang et al. [36], thymol $0.2 \mathrm{mM}$ significantly inhibited the translocation of SipA in an in vitro infection of HeLa cells. This finding indicates that the inhibition of T3SS is the primary protective effect of sub-lethal concentrations of thymol. These data are confirmed in our study, as the same concentration of thymol reduced cell invasion by reducing virulence gene expression, including SipA. Bacteria have, among their survival strategies, the flexibility of altering the mRNA expression patterns in response to environmental stress [37], as for example when cultured with non-lethal concentrations of antimicrobials. Since the mechanism of action of NIC involves the alteration of the bacterial cell membrane and induces an intracellular ATP leakage [29,38], it can be postulated that bacteria subjected to stressful sub-lethal concentrations of NIC switch their energies from motility or virulence systems to vital and essential processes, until a more favorable environment is restored [39]. Recently, it has been demonstrated that a stress induced by thymol influences the S. typhimurium proteome, downregulating genes involved in chemotaxis, motility, and virulence [20]. In addition, it is reported that these substances can affect quorum sensing of bacteria [40], which, in turn, controls virulence factor production [41,42].

It is plausible that the amelioration of TER and the reduction of bacterial translocation across Caco- 2 cells observed in this study was mediated by the downregulation of a panel of several virulence genes that are involved in a complex series of reactions necessary to exploit Salmonella pathogenicity. In particular, we observed a reduction of the expression of the transcriptional activator of invasion HilA, which is the first trigger and activates genes responsible for the assembly of the T3SS structure, including $\operatorname{prg} H$ and invA [11]. HilA upregulation was correlated with tetracycline resistance cases [19], whereas its downregulation is attributed to several bioactive compounds such as short and medium chain fatty acids $[43,44]$. This would support our findings suggesting a possible cascade effect on the expression of $\operatorname{prgH}$ and $i n v A$. The other genes that were significantly downregulated by thymol and carvacrol are all initiators of a cascade of reactions that ultimately ends in cytoskeletal rearrangements and the disruption of TJ proteins, with a consequent increase in paracellular permeability $[16,45,46]$. Ultimately, this would facilitate the passage of Salmonella from the apical side to the basolateral side, thereby ending the Salmonella vicious cycle with a worsening of its pathogenicity [47].

\section{Conclusions}

The data from this study support a dual mechanism of action of thymol and carvacrol in ameliorating the effects associated with a S. typhimurium in vitro challenge. From the host side, thymol and carvacrol have anti-inflammatory and anti-oxidant properties that can prevent the cascade of inflammatory cytokines due to Salmonella infection, and contribute to the maintenance of the epithelial integrity, whereas from the pathogen side these molecules have direct antimicrobial properties that can inhibit the growth of Salmonella, but at the same time at sub-inhibitory concentrations they can alter a set of virulence genes that are responsible for invasion and damage to the epithelium. Since thymol and carvacrol are already widely used as feed additives, after confirming these findings also in vivo, these molecules could be helpful candidates in the control of salmonellosis in pigs.

Author Contributions: Conceptualization, E.G.; methodology, B.R. and B.T.; investigation, G.G., B.R., F.G. and A.B.; writing—original draft preparation, G.G.; writing—review and editing, E.G.; supervision, E.G and A.P. All authors have read and agreed to the published version of the manuscript.

Funding: This research received no external funding.

Acknowledgments: This research was supported by a grant from Vetagro SpA.

Conflicts of Interest: Andrea Piva serves as a professor at the University of Bologna and is a member of the board of directors of Vetagro S.p.A. (Reggio Emilia, Italy). Ester Grilli serves as an advisor of Vetagro S.p.A. 


\section{References}

1. EFSA. The European Union summary report on trends and sources of zoonoses, zoonotic agents and food-borne outbreaks in 2017. EFSA J. 2018, 16, e05500.

2. Centers for Disease Control and Prevention (CDC). National Salmonella Surveillance Annual Report, 2016; US Department of Health and Human Services, CDC: Atlanta, GA, USA, 2018.

3. Barilli, E.; Bacci, C.; StellaVilla, Z.; Merialdi, G.; D’Incau, M.; Brindani, F.; Vismarra, A. Antimicrobial resistance, biofilm synthesis and virulence genes in Salmonella isolated from pigs bred on intensive farms. Ital. J. Food Saf. 2018, 7, 7223. [CrossRef] [PubMed]

4. Fedorka-Cray, P.J.; Gray, J.T.; Wray, C. Salmonella Infections in Pigs. In Salmonella in Domestic Animals; Wray, C., Wray, A., Eds.; CABI Publishing: New York, NY, USA, 2000; pp. 191-208.

5. Farzan, A.; Friendship, R.M. A clinical field trial to evaluate the efficacy of vaccination in controlling Salmonella infection and the association of Salmonella-shedding and weight gain in pigs. Can. J. Vet. Res. 2010, 74, 258-263. [PubMed]

6. Verbrugghe, E.; Van Parys, A.; Leyman, B.; Boyen, F.; Haesebrouck, F.; Pasmans, F. HtpG contributes to Salmonella Typhimurium intestinal persistence in pigs. Vet. Res. 2015, 46, 118. [CrossRef]

7. Verbrugghe, E.; Boyen, F.; Van Parys, A.; Van Deun, K.; Croubels, S.; Thompson, A.; Shearer, N.; Leyman, B.; Haesebrouck, F.; Pasmans, F. Stress induced Salmonella Typhimurium recrudescence in pigs coincides with cortisol induced increased intracellular proliferation in macrophages. Vet. Res. 2011, 42, 118. [CrossRef]

8. Grilli, E.; Foresti, F.; Tugnoli, B.; Fustini, M.; Zanoni, M.G.; Pasquali, P.; Callaway, T.R.; Piva, A.; Alborali, G.L. Microencapsulated sorbic acid and pure botanicals affect Salmonella Typhimurium shedding in pigs: A close-up look from weaning to slaughter in controlled and field conditions. Foodborne Pathog. Dis. 2015, 12, 813-819. [CrossRef] [PubMed]

9. Nieto, P.A.; Pardo-Roa, C.; Salazar-Echegarai, F.J.; Tobar, H.E.; Coronado-Arrázola, I.; Riedel, C.A.; Kalergis, A.M.; Bueno, S.M. New insights about excisable pathogenicity islands in Salmonella and their contribution to virulence. Microbes Infect. 2016, 18, 302-309. [CrossRef]

10. Coburn, B.; Sekirov, I.; Finlay, B.B. Type III Secretion Systems and Disease. Clin. Microbiol. Rev. 2007, 20, 535-549. [CrossRef]

11. Sukhan, A.; Kubori, T.; Wilson, J.; Galán, J.E. Genetic analysis of assembly of the Salmonella enterica serovar Typhimurium type III secretion-associated needle complex. J. Bacteriol. 2001, 183, 1159-1167. [CrossRef]

12. Singh, Y.; Saxena, A.; Kumar, R.; Kumar Saxena, M. Virulence System of Salmonella with Special Reference to Salmonella enterica. In Salmonella A Re-Emerging Pathogen; Mascellino, M.T., Ed.; IntechOpen Limited: London, UK, 2018; pp. 41-53.

13. Finlay, B.B.; Ruschkowski, S.; Dedhar, S. Cytoskeletal rearrangements accompanying salmonella entry into epithelial cells. J. Cell. Sci. 1991, 99, 283-296.

14. Cruz, N.; Qi, L.; Alvarez, X.; Berg, R.D.; Deitch, E.A. The Caco-2 cell monolayer system as an in vitro model for studying bacterial-enterocyte interactions and bacterial translocation. J. Burn Care Rehabil. 1994, 15, 207-212. [CrossRef] [PubMed]

15. Finlay, B.B.; Falkow, S. Salmonella Interactions with Polarized Human Intestinal Caco-2 Epithelial Cells. J. Infect. Dis. 1990, 162, 1096-1106. [CrossRef] [PubMed]

16. Boyle, E.C.; Brown, N.F.; Finlay, B.B. Salmonella enterica serovar Typhimurium effectors SopB, SopE, SopE2 and SipA disrupt tight junction structure and function. Cell. Microbiol. 2006, 8, 1946-1957. [CrossRef] [PubMed]

17. Nair, D.V.T.; Venkitanarayanan, K.; Kollanoor Johny, A. Antibiotic-Resistant Salmonella in the Food Supply and the Potential Role of Antibiotic Alternatives for Control. Foods 2018, 7, 167. [CrossRef] [PubMed]

18. Livak, K.J.; Schmittgen, T.D. Analysis of relative gene expression data using real-time quantitative PCR and the 2(-Delta Delta C(T)) Method. Methods 2001, 25, 402-408. [CrossRef]

19. Weir, E.K.; Martin, L.C.; Poppe, C.; Coombes, B.K.; Boerlin, P. Subinhibitory concentrations of tetracycline affect virulence gene expression in a multi-resistant Salmonella enterica subsp. enterica serovar Typhimurium DT104. Microbes Infect. 2008, 10, 901-907. [CrossRef]

20. Qi, Y.; Zhao, W.; Wang, T.; Pei, F.; Yue, M.; Li, F.; Liu, X.; Wang, X.; Li, H. Proteomic analysis of the antimicrobial effects of sublethal concentrations of thymol on Salmonella enterica serovar Typhimurium. Appl. Microbiol. Biotechnol. 2020, 104, 3493-3505. [CrossRef] 
21. Zhang, J.S.; Corredig, M.; Morales-Rayas, R.; Hassan, A.; Griffiths, M.W.; LaPointe, G. Downregulation of Salmonella Virulence Gene Expression During Invasion of Epithelial Cells Treated with Lactococcus lactis subsp. cremoris JFR1 Requires OppA. Probiotics Antimicrob. Proteins 2019. [CrossRef]

22. Arguello, H.; Rubio, P.; Carvajal, A. Salmonella Control Measures at Farm in Swine Production. In Salmonella-Distribution, Adaptation, Control Measures and Molecular Technologies; Annous, B., Gurtler, J.B., Eds.; IntechOpen Limited: London, UK, 2012; pp. 99-122.

23. Liu, Y.; Espinosa, C.D.; Abelilla, J.J.; Casas, G.A.; Lagos, L.V.; Lee, S.A.; Kwon, W.B.; Mathai, J.K.; Navarro, D.M.D.L.; Jaworski, N.W.; et al. Non-antibiotic feed additives in diets for pigs: A review. Anim. Nutr. 2018, 4, 113-125. [CrossRef]

24. Costa, L.B.; Luciano, F.B.; Miyada, V.S.; Gois, F.D. Herbal extracts and organic acids as natural feed additives in pig diets. S. Afr. J. Anim. Sci. 2013, 43, 181-193.

25. Van Immerseel, F.; Russell, J.B.; Flythe, M.D.; Gantois, I.; Timbermont, L.; Pasmans, F.; Haesebrouck, F.; Ducatelle, R. The use of organic acids to combat Salmonella in poultry: A mechanistic explanation of the efficacy. Avian Pathol. 2006, 35, 182-188. [CrossRef] [PubMed]

26. Windisch, W.; Schedle, K.; Plitzner, C.; Kroismayr, A. Use of phytogenic products as feed additives for swine and poultry. J. Anim. Sci. 2008, 86, E140-E148. [CrossRef] [PubMed]

27. Gómez-García, M.; Sol, C.; De Nova, P.J.G.; Puyalto, M.; Mesas, L.; Puente, H.; Mencía-Ares, Ó.; Miranda, R.; Argüello, H.; Rubio, P.; et al. Antimicrobial activity of a selection of organic acids, their salts and essential oils against swine enteropathogenic bacteria. Porc. Health Manag. 2019, 5, 32. [CrossRef] [PubMed]

28. Guillier, L.; Nazer, A.I.; Dubois-Brissonnet, F. Growth response of Salmonella typhimurium in the presence of natural and synthetic antimicrobials: Estimation of MICs from three different models. J. Food Prot. 2007, 70, 2243-2250. [CrossRef] [PubMed]

29. Helander, I.M.; Alakomi, H.-L.; Latva-Kala, K.; Mattila-Sandholm, T.; Pol, I.; Smid, E.J.; Gorris, L.G.M.; Von Wright, A. Characterization of the Action of Selected Essential Oil Components on Gram-Negative Bacteria. J. Agric. Food Chem. 1998, 46, 3590-3595. [CrossRef]

30. Bearson, S.; Bearson, B.; Foster, J.W. Acid stress responses in enterobacteria. FEMS Microbiol. Lett. 1997, 147, 173-180. [CrossRef]

31. Pinto, M.; Robineleon, S.; Appay, M.D.; Kedinger, M.; Triadou, N.; Dussaulx, E.; Lacroix, B.; Simonassmann, P.; Haffen, K.; Fogh, J.; et al. Enterocyte-Like Differentiation and Polarization of the Human-Colon Carcinoma Cell-Line Caco-2 in Culture. Biol. Cell 1983. Available online: https://www.scienceopen.com/document?vid= 10c4912d-182f-4361-98a7-50c52d5b3617 (accessed on 19 May 2020).

32. Srinivasan, B.; Kolli, A.R.; Esch, M.B.; Abaci, H.E.; Shuler, M.L.; Hickman, J.J. TEER measurement techniques for in vitro barrier model systems. J. Lab. Autom. 2015, 20, 107-126. [CrossRef]

33. Rossi, B.; Toschi, A.; Piva, A.; Grilli, E. Single components of botanicals and nature-identical compounds as a non-antibiotic strategy to ameliorate health status and improve performance in poultry and pigs. Nutr. Res. Rev. 2020, 1-17. [CrossRef]

34. Inamuco, J.; Veenendaal, A.; Burt, S.; Post, J.; Bokhoven, J.; Haagsman, H.; Veldhuizen, E. Sub-lethal levels of carvacrol reduce Salmonella Typhimurium motility and invasion of porcine epithelial cells. Vet. Microbiol. 2011, 157, 200-207. [CrossRef]

35. Burt, S.A.; Adolfse, S.J.M.; Ahad, D.S.A.; Tersteeg-Zijderveld, M.H.G.; Jongerius-Gortemaker, B.G.M.; Post, J.A.; Brüggemann, H.; Santos, R.R. Cinnamaldehyde, Carvacrol and Organic Acids Affect Gene Expression of Selected Oxidative Stress and Inflammation Markers in IPEC-J2 Cells Exposed to Salmonella typhimurium. Phytother. Res. 2016, 30, 1988-2000. [CrossRef]

36. Zhang, Y.; Liu, Y.; Qiu, J.; Luo, Z.-Q.; Deng, X. The Herbal Compound Thymol Protects Mice From Lethal Infection by Salmonella Typhimurium. Front Microbiol. 2018, 9, 1022. [CrossRef]

37. Grantcharova, N.; Peters, V.; Monteiro, C.; Zakikhany, K.; Römling, U. Bistable Expression of CsgD in Biofilm Development of Salmonella enterica Serovar Typhimurium. J. Bacteriol. 2009, 192, 456-466. [CrossRef]

38. Chouhan, S.; Sharma, K.; Guleria, S. Antimicrobial Activity of Some Essential Oils-Present Status and Future Perspectives. Medicines 2017, 4, 58. [CrossRef]

39. Yuan, W.; Yuk, H.-G. Effects of Sublethal Thymol, Carvacrol, and trans-Cinnamaldehyde Adaptation on Virulence Properties of Escherichia coli O157:H7. Appl. Environ. Microbiol. 2019, 85, 1-11. 
40. Nazzaro, F.; Fratianni, F.; D’Acierno, A.; Coppola, R.; Ayala-Zavala, F.J.; Da Cruz, A.G.; Feo, V.D. Essential Oils and Microbial Communication. In Essential Oils-Oils of Nature; El-Shemy, H., Ed.; IntechOpen Limited: London, UK, 2019; pp. 1-26.

41. Rutherford, S.T.; Bassler, B.L. Bacterial quorum sensing: Its role in virulence and possibilities for its control. Cold Spring Harb. Perspect Med. 2012, 2, 1-25. [CrossRef]

42. Choi, J.; Shin, D.; Ryu, S. Implication of Quorum Sensing in Salmonella enterica Serovar Typhimurium Virulence: The luxS Gene Is Necessary for Expression of Genes in Pathogenicity Island 1. Infect Immun. 2007, 75, 4885-4890. [CrossRef]

43. Gantois, I.; Ducatelle, R.; Pasmans, F.; Haesebrouck, F.; Hautefort, I.; Thompson, A.; Hinton, J.C.; Immerseel, F.V. Butyrate Specifically Down-Regulates Salmonella Pathogenicity Island 1 Gene Expression. Appl. Environ. Microbiol. 2006, 72, 946-949. [CrossRef]

44. Boyen, F.; Haesebrouck, F.; Vanparys, A.; Volf, J.; Mahu, M.; Van Immerseel, F.; Rychlik, I.; Dewulf, J.; Ducatelle, R.; Pasmans, F. Coated fatty acids alter virulence properties of Salmonella Typhimurium and decrease intestinal colonization of pigs. Vet. Microbiol. 2008, 132, 319-327. [CrossRef]

45. Hallstrom, K.; McCormick, B.A. Salmonella Interaction with and Passage through the Intestinal Mucosa: Through the Lens of the Organism. Front. Microbiol. 2011, 2, 1-10. [CrossRef]

46. Tafazoli, F.; Magnusson, K.-E.; Zheng, L. Disruption of Epithelial Barrier Integrity by Salmonella enterica Serovar Typhimurium Requires Geranylgeranylated Proteins. Infect Immun. 2003, 71, 872-881. [CrossRef]

47. Köhler, H.; Sakaguchi, T.; Hurley, B.P.; Kase, B.A.; Kase, B.J.; Reinecker, H.-C.; McCormick, B.A. Salmonella enterica serovar Typhimurium regulates intercellular junction proteins and facilitates transepithelial neutrophil and bacterial passage. Am. J. Physiol. Gastrointest. Liver Physiol. 2007, 293, G178-G187. [CrossRef]

(C) 2020 by the authors. Licensee MDPI, Basel, Switzerland. This article is an open access article distributed under the terms and conditions of the Creative Commons Attribution (CC BY) license (http://creativecommons.org/licenses/by/4.0/). 